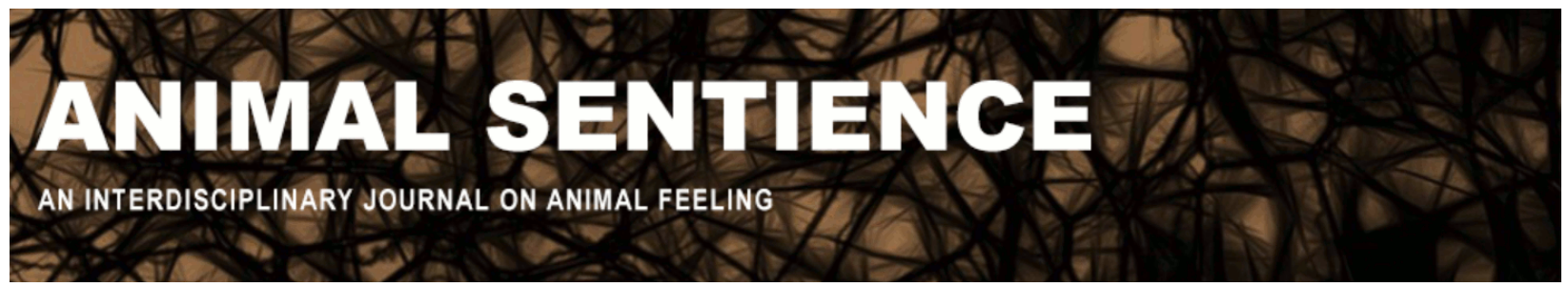

Feigin, Svetlana (2020) It does not cost the earth to be kind. Animal Sentience 30(13)

DOI: $10.51291 / 2377-7478.1642$

Date of submission: 2020-09-07

Date of acceptance: 2020-09-07

(c) $\underset{\mathrm{EY}}{\mathrm{C}}$

This article has appeared in the journal Animal

Sentience, a peer-reviewed journal on animal

cognition and feeling. It has been made open access,

free for all, by WellBeing International and deposited

in the WBI Studies Repository. For more information,

please contact

wbisr-info@wellbeingintl.org.

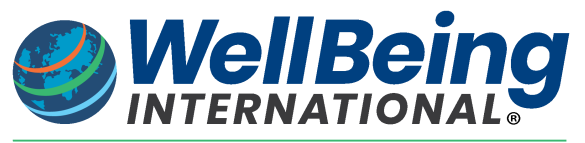

SOLUTIONS FOR PEOPLE, ANIMALS AND ENVIRONMENT 


\title{
It does not cost the earth to be kind
}

Commentary on Wiebers \& Feigin on Covid Crisis

\section{Svetlana Feigin}

\begin{abstract}
The COVID-19 crisis is a wake-up call on a global scale. What lessons we learn from this crisis will determine our survival as a species. The global health crisis calls for individual and collective changes in our agricultural practices and our consumption habits. Most important, it is a call for us as a species to move towards an empathic way of living and interacting with nature.
\end{abstract}

\begin{abstract}
Svetlana Feigin's research and publications focus on human empathy and altruism, the personal experiences of activists and public perceptions of altruistically motivated crimes. Website
\end{abstract}

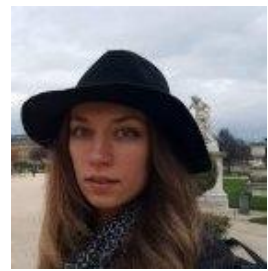

1. Individual and collective action. Wiebers \& Feigin (2020) (W\&F) focus on what actions need to be taken to prevent future pandemics. The link between intensive animal farming, the disruption of wild habitats, and zoonotic diseases has been well established. The target article does not focus exclusively on live-animal markets in parts of Asia but on our relationship with animals and nature overall, including Western animal agriculture practices. The global COVID-19 pandemic demonstrates that those in the Western world can no longer assume that this does not concern "us." It has forced nations worldwide into action to reduce and prevent the spread of the virus. Governments need to go further, however, adopting strategies for a transition to an alternative to intensive animal agriculture. Citizens need to become conscientious, compassionate consumers, voting with their wallets to stop supporting factory farming.

2. If not for animal rights, then for human welfare. One of the major challenges of animal rights activism is how to educate people about animal rights and welfare in practices such as factory farming and the consumption of animal products (Feigin, Owens et al. 2018). If the countless media exposures of animal suffering (as in documentaries such as Earthlings) are not enough to inspire humans to stop supporting the animal agriculture industry, then perhaps the current global human health crisis will be.

Since the explosion of COVID-19 across the planet, video footage has emerged on social media displaying the graphic evidence of what happens in "wet markets" (live animal markets). Such environments are ideal breeding grounds for viruses. But so too are factory farming and intensive animal agriculture, including the problem of antibiotic resistance (Martin, Thottathil et al. 2015). W\&F draw the inescapable conclusion that we must "rapidly evolve to eating other forms of protein that are safer for humans, including plant-based meat alternatives and cultured meat."

3. Empathy and compassion. Research has by now amply demonstrated that most nonhuman animals (including all those we deem "livestock") are sentient and complex individuals (Broom et al. 2009; Mendl et al. 2010; Klein \& Barron 2016; Kujala 2017; Marino 2017; Cook et al. 2018; Marino \& Merskin 2019; Mather 2019; Mikhailovich \& Powell 2020). Yet our perception of being "superior" to non-human animals (Chapman and Huffman 2018) has 
given us an excuse to subjugate and use them for our benefit at a cost of unimaginable cruelty and suffering. It does not cost the earth to be kind, but it may cost us the earth if we allow economic interests to override welfare and health concerns. Factory farming, deforestation, and mass animal exploitation are only a few examples of the anthropogenic harm our species is currently causing (Treves et al. 2019; Baker \& Winkler 2020). As W\&F note: "What is good for nonhumans and the earth is virtually always in the best interests of humans." When it is deemed ethical to cram unimaginably large numbers of animals into confined spaces as the predominant farming model for most of the world, animals suffer, people suffer, and the biosphere destabilizes.

\section{References}

Baker, Liv and Winkler, Rebecca (2020) Asian elephant rescue, rehabilitation and rewilding. Animal Sentience 28(1)

Broom, D. M., Sena, H., \& Moynihan, K. L. (2009). Pigs learn what a mirror image represents and use it to obtain information. Animal Behaviour, 78(5), 1037-1041.

Chapman, C. A. and M. A. Huffman (2018). Why do we want to think humans are different? Animal Sentience 23(1).

Cook, P.; Prichard, A.; Spivak, M.; and Berns, G. S. (2018) Jealousy in dogs? Evidence from brain imaging. Animal Sentience 22(1)

Feigin, S., et al. (2018). A Clean, Green New Zealand? An In-Depth Look at the Personal Experiences of Animal Rights Activists. The Qualitative Report 23(3): 616-635.

Klein, C. and Barron, A. B. (2016) Insects have the capacity for subjective experience. Animal Sentience 9(1)

Kujala, M. V. (2017) Canine emotions as seen through human social cognition. Animal Sentience 14(1)

Marino, L. \& D. Merskin (2019). Intelligence, complexity, and individuality in sheep. Animal Sentience 25(1).

Marino, L. (2017) The inconvenient truth about thinking chickens. Animal Sentience 17(1)

Martin, M. J., et al. (2015). Antibiotics Overuse in Animal Agriculture: A Call to Action for Health Care Providers. American Journal of Public Health 105(12): 2409-2410.

Mather, J. (2019) What is in an octopus's mind? Animal Sentience 26(1) Mendl, M., Held, S., \& Byrne, R. W. (2010). Pig cognition. Current Biology, 20(18), R796-R798.

Mikhalevich, I. and Powell, R. (2020) Minds without spines: Evolutionarily inclusive animal ethics. Animal Sentience 29(1)

Treves, Adrian; Santiago-Ávila, Francisco J.; and Lynn, William S. (2019) Just preservation. Animal Sentience 27(1)

Wiebers, D. O. and V. L. Feigin (2020). What the COVID-19 crisis is telling humanity. Animal Sentience 30(1). 